\title{
THE EFFECT OF CURRENT PUBLIC PROCUREMENT LAW ON DURATION AND COST OF CONSTRUCTION PROJECTS IN TURKEY
}

\author{
Ercan Erdis \\ Department of Civil Engineering, Engineering Faculty, Mustafa Kemal University, \\ 31200 Iskenderun, Turkey \\ E-mail:eerdis@mku.edu.tr \\ Received 30 May 2011; accepted 19 Mar. 2012
}

\begin{abstract}
The current public procurement law (Law No. 4734) was established in Turkey in 2003. The current law has fundamental differences from the previous one, Law No. 2886, in that the current law's main objective is to increase the effective use of public resources. Although the current law was enacted nine years ago, no in-depth research has been undertaken related to the extent of public savings. Thus, the aim of this research is to analyze the performance of public investments for construction with respect to their success in achieving on time and within budget completion. Additionally, a comparison between the completion duration and budget of construction projects undertaken under the current and the previous law is presented. To achieve these goals, historical contract documents addressing 878 and 575 public construction projects undertaken under two laws, respectively, were analyzed. In this context, the data mining method, including decision trees, artificial neural network, and support vector machines, was applied to predict the duration and cost deviations of the construction projects during the tender process, and the results were compared. It was demonstrated that the current law has contributed substantially towards the completion of the projects within estimated or envisaged durations and costs. The findings of this research can be generalized to countries with similar economical and organizational structures with Turkey.
\end{abstract}

Keywords: public procurement law, duration variances, cost, estimate, contract price.

\section{Introduction}

The construction sector in Turkey contributes to country's total Gross National Product (GNP) at a level of $4-7 \%$, reaching a level of $33 \%$ when combined with other related sectors. The sector also provides employment to 1.4 million people, equivalent to $6 \%$ of registered employment in Turkey (Saritas 2006; Construction Sector 2011). In Turkey, public investment has a $4 \%$ share in the Gross Domestic Product (GDP), representing approximately $35 \%$ of the total construction investments. Thus, the construction sector is directly affected by changes in the procurement (tender) system. If these changes are not made rationally, significant deviations, especially in estimating duration and costs of investment programs may occur. Therefore, it is crucial to have a procurement system with transparent and competitive conditions for the effective use of public resources. For this reason, some improvements have been made periodically to the procurement laws governing Turkey's public purchases. For example, the Public Procurement Law (Law No. 2886), which was first enacted in 1984, was revised several times. However, the revisions did not include improvements to the basic principles, and thus, did not contribute much to reducing the waste of national resources.

More recently the procurement law has been completely rearranged based on the principles of the European
Union public procurement system within the harmonization process related to European Union accession of Turkey. This law, titled "The Current Public Procurement Law (Law No. 4734)" was enacted in 2003. The arrangements within this law aim to contribute to the effective use of public resources by providing a competitive market and transparency in public procurement tenders. The current law has been implemented for nearly nine years. However, comprehensive research on the level of contribution of this law to the effective use of public resources is yet to be conducted. Thus, the present study was conducted to determine the level of contribution of the current public procurement law to reducing duration and cost deviations, taking into consideration the significant size of construction investments in public expenditure. In this study, the effects of changes in tenders on the duration and costs of construction projects were investigated due to their large share of public procurement. To achieve this objective, archival (historical) data of completed construction investments tendered with the old and current laws were examined, and the results obtained were analyzed. First, the 878 units of public procurement construction investment files tendered under the old law between the years 2002-2009, and 575 units in under the current law (combined totaling 1453 units), were examined to investigate whether duration and cost deviated. It was further researched whether the deviations in duration and 
cost of the construction projects can be predicted using data mining (DM) methods, including decision trees (DT), artificial neural network (ANN), and support vector machines (SVM), even during the tender process. In the research findings and discussion section, the construction investments within the context of both laws are compared regarding project duration, cost deviations, and the level of improvement achieved by the change of the procurement system. In this context, the differences between the estimated and actual completion duration and cost of the investments, tendered according to the previous and current laws, are investigated, and the findings are discussed by comparing with the existing literature (Gönen, Işık 1997; Gören 1998; Karslı 1998; Güreş 1998; Bhokha, Ogunlana 1999; Dissanayaka, Kumaraswamy 1999; Akintoye 2000; Wright, Williams 2001; Williams 2002; Göçerler 2002; Gök 2003; Skitmore, Ng 2003; Kim et al. 2004; Koushki et al. 2005; Elhag et al. 2005; Turhan 2006; Cheng et al. 2010; Yakut, Elmas 2011; Wang et al. 2012).

\section{Effective public procurement system}

Effective purchasing (i.e., the purchase of high-quality goods and services at low cost by public institutions) is essential for effective use of the budget, particularly in developing countries such as Turkey. This is, however, only possible by the establishment of an effective public procurement system.

Public procurement is the purchase process of goods and services, including construction services, needed to serve the public by the government (European Union Delegation of the European Commission to Turkey 2000). Many studies have been conducted to increase the efficiency of purchases held in the public and private sectors. Academic studies, such as the contractor selection methodology (Holt 1998), the military procurement (Strain, Preece 1999), the electronic procurement system (Liao et al. 2002), the new purchasing systems (Luu et al. 2003), and procurement methods (Tserng, Lin 2002; Tzeng et al. 2006) provide examples showing the importance of an effective public procurement system.

While an effective public procurement system is an important requirement for all countries, it has greater significance particularly for developing countries like Turkey, since public expenditure in developing countries constitutes an important part of economic activities when compared with developed countries (Emek 2001). For example, the public procurement tendered according to the procurement procedures in Turkey in 2010 alone was approximately 22,187,000 Euro (Table 1) (Kamu İhale Kurumu 2011). The experience of the European Union has shown that savings of up to $10 \%$ can be achieved through open public tender, which equates to around 90 billion Euro each year (European Union Delegation of the European Commission to Turkey 2000). Therefore, the positive changes in the public procurement system in Turkey and other developing countries would certainly be expected to provide greater savings opportunities.
Table 1. Distribution and total amount of purchases by type in 2010

\begin{tabular}{l|c|c|c|c}
\hline \multirow{2}{*}{$\begin{array}{c}\text { Distribution of } \\
\text { public purchase }\end{array}$} & \multicolumn{2}{|c|}{$\begin{array}{c}\text { Number of public } \\
\text { purchases }\end{array}$} & \multicolumn{2}{c}{$\begin{array}{c}\text { Total cost of public } \\
\text { purchases } \\
\text { (1000 Euro) }\end{array}$} \\
\cline { 2 - 5 } & Frequency & \% & Cost & $\%$ \\
\hline $\begin{array}{l}\text { Procurement of } \\
\text { goods }\end{array}$ & 38,842 & 44.15 & 5871 & 26.46 \\
\hline Purchase of service & 31,992 & 36.36 & 8669 & 39.07 \\
\hline Construction works & 17,142 & 19.48 & 7647 & 34.47 \\
\hline Total amount & $\mathbf{8 7 , 9 7 6}$ & $\mathbf{1 0 0 . 0 0}$ & $\mathbf{2 2 1 8 7}$ & $\mathbf{1 0 0 . 0 0}$ \\
\hline
\end{tabular}

Source: 12 month procurement statistics of public procurement agency in 2010 (Kamu İhale Kurumu 2011)

\subsection{Effective public procurement system in the European Union}

The main sources of the EU procurement regulations consist of "Primary Legislation" such as the Treaty of Rome; "Secondary Legislation" such as the treaties of participation to the EU and legally binding legislations (including regulations, directives, and decisions); and non-binding legislations such as recommendations and opinions (Ertaş 2010). With an average 1500 billion Euros of market value, procurement contracts have a huge market share. Therefore, the principles for the controlled and efficient use of the market are determined by the European Union Procurement Directives (Gorecki 2006). In this regard, the EU regulates goods, services, and construction work altogether by the Consolidated Directive of 2004/18 EC, dated 31.03.2004 (Yalazay 2010; Ertaş 2010).

The criteria to be considered by the administration as the basis of tenders are regulated in Article No. 53 of the directive. Accordingly, two methods are considered. First, after the administration determines the degree of importance of criteria such as quality, price, technical merit, aesthetic and functional features, current expenses, cost-effectiveness, after-sales service, technical assistance, and delivery time, the bid that most satisfies the criteria for the weighted values is chosen. This method is referred to as the "most economically advantageous tender" method (Arrowsmith, Kunzlik 2009). The second method is to choose the tender with the lowest price. At this stage, the administration should clearly advertise the method to be used. If the most economically advantageous tender method is to be used, the criteria and their level of importance are already specified in the directives. As apparent from the above discussion, the EU public procurement directives set the general framework for public procurement, but the detailed arrangements have been left to the member states.

While there are plans to use recent technological developments in the procurement system, new procurement procedures such as dynamic purchasing systems and electronic auctions, which have not been applied before, are included in these directives. The effect of these amendments is considered to be positive: the flexibility of units engaged in the tendering of contracts is increased 
with frame contracts, and greater flexibility and innovation are achieved with the changes in consideration of environmental and social concerns within technical criteria. Although the competitive dialogue procedure will show its merit in time, further guidance and interpretations are needed (Ertaş 2010).

In EU Classic Directive No. 2004/18/EC and Sector Undertakings Directive No. 2004/17/EC, threshold values are given for the goods, services, and construction work (European Commission [EC] decision numbered No. 1777/2009), and it is specified that the directives will be implemented in public procurements where the estimated cost is equal to or higher than the threshold values. Although implementing the directives in public procurements where the estimated cost is lower than the threshold values is not required, it is recommended that these procurements be carried out without violating the rules on free movement of goods and services of the EU Treaty rules.

As the changes made so far in this direction on EU Public Procurement Directives are tracked, it is seen that the factors impeding competition were reduced by increasing transparency and competition, bidding procedures were rendered simpler and more understandable, and flexibility was increased. In addition, as would be expected, as alternatives consisting of technological developments that benefit authorities in public procurement tenders were introduced, the bureaucracy and the time were reduced through electronic applications, and as a result, effectiveness and efficiency were increased in the public purchases.

\subsection{Public procurement system in Turkey}

The final arrangement on the existing public procurement system was undertaken in 1983. The State Procurement Law (Law No. 2886), which started to be practiced on 01.01.1984 (Resmi Gazete 1983), did not undergo a fundamental revision until 2003. The old law was based on "unit price" as the tender procedure. This law became one of the factors impairing the effectiveness of public expenditures, and therefore, necessitated a new system to be introduced urgently due to the followings concerns: (1) the law did not cover all public institutions and satisfy the changing needs of these institutions; (2) it was insufficient to resolve emerging deficiencies; and (3) it was not compatible with the European Union and international procurement practices. For this reason, a public procurement system enabling effectiveness had priority and urgency with the process of Turkey's candidacy for full EU membership. Thus, the Current Public Procurement Law (Law No. 4734) was enacted on 01.01.2003 (Resmi Gazete 2002).

Under the current law, public procurements were collected in three main groups: construction, services, and supplies. The general procedures that apply to all contracts and purchase details are defined by the same law. With the current procurement law, the following objectives are targeted: (1) ensuring transparency, competition, equal treatment, reliability, confidentiality, and public inspection; (2) meeting the needs appropriately and timely; (3) ensuring, in the widest sense, the efficient use of resources; (4) covering all public institution tenders within a single legal regulation; and (5) getting tenders which are based on realistic prices that reflect current market conditions. In other words, the level of effectiveness has been increased in public tenders by the application of this law.

With the previous law, it was generally acknowledged that public construction investments caused significant waste of public resources because they took a longer time and costed more than expected. As stated by various authors (Gönen, Işık 1997; Gören 1998; Abacioğlu 1999; Paydak 2002; Öcal et al. 2006), the duration and cost increases in construction projects that were carried out by Law No. 2886 originated from several factors, such as: (1) insufficient detail in the preparation of the contracts and supplements; (2) incompleteness of contractor selection methods (e.g., lack of a detailed price analysis because the old law used unit price methods as the tender procedure); (3) lack of the application of management functions (i.e., planning, organization, coordination, command, and control) from the beginning to the end of the work due to various reasons; (4) low values of production productivity due to various reasons; and (5) external factors such as negative market conditions and price changes.

The current procurement system has provided significant improvements in these areas (Paydak 2002; Arslan 2002; Gencer 2003; Gök 2003; Öcal et al. 2006). For example, the former procurement law allowed tendering with estimated costs (first estimated cost) without preparing detailed designs (i.e., the bidders had the right to execute projects with a cost discount, resulting in an increase in quantities and quality of work during the construction phase). This situation caused the investments to be finished over a longer time period and at higher costs, resulting from both the misestimating of approximate costs and the improper allocation of resources. In addition, since there was no requirement for the allocation of necessary resources in expenditures for investments, many investments began with uncertainties about resource requirements and priorities, leading to delays in investments for years that resulted in large-scale wastes of public resources.

The "Turnkey" tender type is envisaged in the current law for the purpose of enabling a tender based on realistic costs (approximately cost) and prepared by bidders with detailed engineering specifications and with prices on par with market rates. Another important revision in the current law is that bidding is not allowed unless detailed designs are prepared, excluding unexpected events defined by law (e.g., earthquakes and natural disasters). The current procurement law requires sufficient money to be allocated at the beginning of the investment and also prevents a reduction of the amount of scheduled annual payments for future years. This has contributed to the effective use of public resources. Despite this positive outlook, various authors have stated that duration and cost increases have occurred rarely in construction pro- 
jects under Law No. 4734 due to failure in the application of management functions during the implementation of the work and to various external factors (Paydak 2002; Öcal et al. 2006).

Regarding the above-mentioned improvements on Public Procurement Law, Public Procurement Law in Turkey and the European Union seems to have similar provisions. However, in practice, there are still differences between the Public Procurement Law in Turkey and the European Union's Public Procurement Law System, especially in determining the bid price. Administrations in the European Union and Turkey carry out the public procurement system on the basis of either the most economically advantageous tender or the lowest price. The European Union clearly announces the method to be used in each application. In the case of the most economically advantageous tender method, the level of importance of each criterion is determined in proportion with the criteria weights. However, in Turkey this is not clearly stated in the advertisements, and the economically most advantageous bid may be the one with the lowest price during tendering. Even when the lowest price method is not possible in the tenders, this method may be selected by taking into account the non-price criteria. The economically most advantageous tender criteria (e.g., after-sales service or technical assistance) differ partly from criteria of the European Union. This and similar cases partly affect the project cost and time and for this reason, those estimated various computational-based models.

\section{Models used for estimating duration and cost deviations in construction projects}

Deviations in duration and cost are common in civil construction projects throughout the world. Whilst various models have been developed for realistic duration/cost predicts, there has been resistance from construction professionals to the use of such models due to the lack of software integration models and modular functionality. The modeling tools used are classified into four groups (Kanoğlu 2003):

- Experience-based (i.e., algorithms, heuristics, expert system programming);

- Simulation-based (i.e., heuristics, expert models, decision rules);

- Parametric-based (i.e., regression, statistical models, data mining methods);

- Discrete state-based (i.e., linear programming, classical optimization, network).

Recent models attempt to undertake estimate/predict by using alternative approaches and techniques, including multiple linear regression and factor analysis, expert systems, and data mining methods.

\subsection{Multiple linear regression and factor analysis}

Multiple linear regression and factor analysis models are used by several authors for estimating project duration and cost in the construction industry (Skitmore, $\mathrm{Ng} 2003$; Chan, Kumaraswamy 1999; Akintoye 2000; Akintoye, Fitzgerald 2000; Williams 2003; Chan, Park 2005; Abu
Hammad et al. 2008; Dursun, Stoy 2011; Doloi et al. 2012).

Bromilow (1969) developed a regression model (commonly known as Bromilow's time-cost (BTC) model for estimating contract duration based on the estimated final cost of a construction project (Skitmore, $\mathrm{Ng}$ 2003).

Chan and Kumaraswamy (1999) identified a set of significant variables (e.g., project characteristics and construction cost) influencing construction durations of projects in Hong Kong, and they formulated standard norms for overall construction durations of public housing projects by modeling the primary work packages in the building process on the basis of the identified groups of critical factors. For estimation of duration at the early design stage from limited project information, data were analyzed through multiple linear regression model. This model was then tested and validated using information from the Housing Authority.

Akintoye (2000) exposed the factors influencing contractors' cost estimating practices through analysis of variance and factor analysis. The author identified the main factors relevant to cost estimating practice as market conditions, the client's financial position, buildability, project characteristics and requirements, method of construction, and contract requirements. Akintoye and Fitzgerald (2000) examined, by means of empirical analysis, the cost estimating practices of various contractor categories and major causes of inaccurate cost estimates. The authors demonstrated the shortcomings of cost estimating currently being practiced as: (1) a lack of practical knowledge of the construction process by those responsible for the estimating function; (2) insufficient time to prepare cost estimates; (3) poor tender documentation; and (4) the wide variability of subcontractors' prices.

Williams (2003) stated that separate regression models can predict completed project cost using only the project's low bid as input for competitively bid highway projects. Skitmore and Ng (2003) developed standard regression and cross validation regression analysis models for actual construction duration estimates when client sector, contractor selection method, contractual arrangement, project type, contract period, and contract sum were known. A set of 93 Australian construction projects was used to develop the model.

Chan and Park (2005) identified individual factors that contribute to project cost, and they constructed a predictive project cost model using the asymptotic principal component technique. Furthermore, the model was provided a decision support tool to estimate project cost more accurately.

Abu Hammad et al. (2008) developed statistical regression models and sample tests to estimate project cost and duration based on historic performance data (i.e., project type, job type, project area, original bid price, and original project duration) using data from 140 actual projects.

Dursun and Stoy (2011) provided precise estimates of construction duration using the BTC model on 246 projects from 25 different countries. Doloi et al. (2012) 
developed factor analysis and regression models to examine the significance of the key factors impacting delay using a questionnaire and through personal interviews in the Indian construction industry. Factor analysis results showed that the most critical factors leading to construction delay were: (1) lack of commitment; (2) inefficient site management; (3) poor site coordination; (4) improper planning; (5) lack of clarity in project scope; (6) lack of communication; and (7) substandard contract. Regression modeling indicated that poor labour productivity and architects' reluctance for change and rework due to mistakes in construction were the reasons that significantly contributed to the overall delay of the projects. These findings were stated to be significantly important for the Indian construction industry in controlling time overruns in contracts.

\subsection{Expert systems}

Expert-based models are used by several authors for estimating duration and cost of construction projects.

Kanoğlu (2003) developed a performance-based duration estimation model integrated with an automation system model, named the Multi-phase Integrated Automation System (MITOS), which was designed primarily for design/build firms.

Yoo (2007) developed a comprehensive cost estimating model that incorporated Multivariate Probabilistic Analysis (MPA) and Bayes' Theorem. The operation of this model was based upon information reported (e.g. actual cost data for completed work packages) during project executions. Furthermore, this research proposed a mathematical model, called the Information-Based Forecasting Model (IFM), which was based on the use of Sshaped growth curves and Bayesian Inference for forecasting a project's completion date.

Kim (2011) identified the Case-Based Reasoning (CBR) method to improve the accuracy of estimating construction cost in the planning phase for railroad bridges. Also, Genetic Algorithm was utilized to optimize attribute weights in this study. However, in spite of the effectiveness of the CBR model, the author stated that the case database has not been built to fully reflect the diverse superstructures of the railroad bridges.

Zhiliang et al. (2011) explored the application and extension of the Industry Foundation Classes (IFC) standard and Building Information Modeling (BIM)-based application software in experience-based construction cost estimating for tendering for Chinese standards. The authors stated that the IFC-based information model can be applied to the development of a construction cost estimating software.

\subsection{Data mining methods}

Data mining is a process to uncover previously undiscovered information in a data set for decision-making and performing action plans, based on a variety of data stored in the data set; it is the task of obtaining the "valuable" information from large-scale data. In this way, it is possible to reveal the relationships in the data and to make estimates for the future, if necessary (Özmen 2001). To be successful, the estimate is expected to correspond to $75 \%$ of the learning process (Yakut, Elmas 2011). Data mining methods can be divided into two major categories: supervised and unsupervised.

Unsupervised methods are generally intended to understand, recognize, and discover the data and provide ideas for the next method. At the same time, the purpose of these models is to discover hidden information in the input variables. Hierarchical Clustering (HC) and Self Organized Maps (SOM) are used for the unsupervised data mining techniques.

Supervised methods are used to derive information and results from the data. In supervised learning, which is also referred to as learning from example, data are separated according to predetermined criteria by a controller, with various examples given for each class. The purpose of the system is to detect the features for each class from the given example and express these with rule statements (Akpınar 2000). This form of learning has been used in different techniques. For this purpose, techniques such as Decision Trees (DT) analysis, particularly Support Vector Machines (SVM) and Artificial Neural Networks (ANN), have been successfully applied in construction related areas (Bhokha, Ogunlana 1999; Dissanayaka, Kumaraswamy 1999; Wright, Williams 2001; Williams 2002; Kim et al. 2004; Cheng et al. 2010; Yakut, Elmas 2011; Wang et al. 2012).

SVM, ANN, and DT are learning techniques based on the minimization of structural risk and statistical learning theory, involving sample data classification using linear models and training and testing of data instances. Bhokha and Ogunlana (1999) developed an ANN model that uses twelve factors affecting duration performance in construction (e.g., building function, structural system, and functional area) to estimate the construction duration of buildings at the pre-design stage. Dissanayaka and Kumaraswamy (1999) reported that ANN had superior prediction capabilities when compared with Multiple Linear Regression (MLR) for determining duration and cost performance.

Wright and Williams (2001) presented regression and neural network models to estimate completed construction cost, based upon characteristics of the submitted bids on 298 highway construction projects. Due to ease of use, the regression model was preferred over the neural network model.

Williams (2002) developed neural network and regression models to sensitively estimate the completed cost of competitively bid highway projects. However, the author reported that these models could not estimate unusually large cost increases during construction.

Kim et al. (2004) examined the performance of the cost estimation models of Multiple Regression Analysis (MRA), Neural Networks (NNs), and case-based reasoning (CBR) for the data of 530 historical costs of residential buildings between 1997 and 2000 in Seoul, Korea. The best NN model gave more accurate estimation results than the CBR or MRA models. But the authors pointed out that the CBR estimating model performed better than 
the NN estimating model with respect to long-term use, available information from results, and time versus accuracy tradeoffs.

Cheng et al. (2010) proposed an Estimate at Completion (EAC) prediction method using the Evolutionary Support Vector Machine Inference Model (ESIM) that employs genetic algorithm (fmGA) and SVM for estimating final project costs artificial more reliably. The authors examined practical values of the EAC model to determine potential problems to help project managers with effective control, and the learning results were validated in real applications that showed good performance for training models.

Yakut and Elmas (2011) developed DTs and the Discriminant Analysis Model (DAM) to estimate the financial failure of 140 industrial enterprises trading on the International Securities Exchange by way of using the control group and the data set between the year 2005 and 2008.

Wang et al. (2012) outlined the development of artificial NN ensembles and support vector machine classification models to predict project cost and schedule success, using the status of early planning as the model inputs. The authors obtained similar results showing that SVM and ANN ensemble techniques provide better results than single ANN models and that the proposed artificial intelligence models produce satisfactory prediction results.

\section{Materials and methods}

The main purpose of this study is to analyze the performance of public investments for construction with respect to their success in achieving on time and within budget completion. Hence, a comparison between the completion duration and cost of construction projects undertaken under the current and the previous law is presented. Additionally, in the study is to investigate whether the probable deviations in the estimated or envisaged duration and cost (the first estimated cost from Law No. 2886 and the approximate cost from Law No. 4734) of construction investments in the public sector can be estimated during the tender process. Therefore, the duration and cost deviations occurring in construction projects that were tendered under old and current procurement laws were compared. Then, whether the deviations in duration and cost of construction projects can be estimated, even during the tender process, was investigated.

\subsection{Analysis of duration and cost deviations in construction projects carried out under the old and current public laws}

In this part of the study, the historical duration and cost data for construction projects that were tendered and executed under Laws No. 2886 and 4734 have been gathered to investigate deviations in cost and duration of the projects tendered and constructed. For this purpose, a total of 1453 units of tender files in 7 cities have been analyzed. The data were gathered from the archives of Provincial Directorates of Public Works and Settlement in Ankara, Kayseri, Adana, Mersin, Gaziantep, Osmaniye, and Hatay and also from an academic study on this subject (Turhan 2006).

The bidding certifications, contracts, work programs, temporary and final acceptance protocols, and progress payment documents for the construction projects were examined, and the collected data were classified as presented in Tables 2-6. All project costs presented in these tables was extended to 2010 by using "day coefficients" published annually by the government.

The level of deviations in duration and cost for the construction projects carried out under old and current law were compared. Based on the deviations in the duration of the work and the cost of the investment, the investment was characterized as successful or unsuccessful. Then, the findings were interpreted, and some suggestions were made.

\subsection{Prediction of duration and cost deviations in construction projects carried out under the old and current public laws: Method of data mining}

In this part of the study, data mining was used to predict cost and duration deviations in construction projects that were carried out under the old and current laws. Also investigated was whether the deviations in the expected duration and estimated cost of the projects can be estimated during the tender process. In this context, factors affecting duration and cost performance in construction works were investigated under the five main topics, in accordance with the above literature:

- Characteristics of the contract and its supplements (particularly, the type of projects, administrative and technical characteristics of projects, and technical specifications);

- Procurement methods;

- Performance in the implementation of management functions (planning, organization, coordination, and command and control activities);

- Labor productivity;

- External conditions (such as country and market conditions and the wide variability of subcontractors' prices and project area).

Of course, the main factors affecting duration and cost performance and the reasons giving rise to these main factors need to be determined very accurately for correct duration and cost analysis and estimation for each project at both design and construction stages. These data should then be used in the analysis to be conducted. However, the current study considers only the historical data existing in the tender process files of the 1453 construction projects. Thus, the duration and cost deviations in construction projects carried out by Laws No. 2286 and 4734 were compared using the variables existing in these files. In this way, whether these deviations can be estimated or not, even during the tender process, was determined. As a result of the examination of the data in these files, the analysis and estimation of duration and cost deviations have identified five factors that are strongly noted by various authors in the literature (Bhokha, Ogunlana 1999; Akintoye 2000; 
Wright, Williams 2001; Williams 2003; Kim et al. 2004; Turhan 2006; Abu Hammad et al. 2008; Doloi et al. 2012). These factors are:

- The procurement law under which the project is executed;

- The project estimated cost (the first estimated cost from Law No. 2886 and the approximate cost from Law No. 4734);

- The estimated or envisaged duration of the project;

- The rate of price-cut;

- Location/provincial of project.

Furthermore, deviations have been predicted by using DTs, ANNs, and SVMs. The Clementine 12.0 software package programmer was used to implement the techniques and also undertake the analysis. Input data to the programme were the factors that caused duration/cost deviations of the projects and information about the success of the investments. Then, $80 \%$ of the data were used for training and the remaining $20 \%$ for testing. The findings (predicts) have been compared with analysis results of completed projects under the old and current public laws. The study identified that duration/cost deviations can be estimated during the tendering process. The reasons for deviations have also been identified using the DT technique algorithm.

\section{Research findings and discussion}

The durational and cost deviations in construction projects under both the old and current public laws are analyzed below, followed by a discussion of duration and cost deviation prediction.

\subsection{Analysis of durational deviations in construction projects carried out under the old and current public laws}

In this study, project completion levels of the investments tendered between 1995 and 2009 under Laws No. 2886 and 4734 were determined separately on the basis of completion years of the projects. To obtain more meaningful results, the analysis was carried out by considering and comparing the total number of the projects tendered under these laws.

During the study, to determine durational deviations of the projects tendered between 1995 and 2009 under Laws No. 2886 and 4734, "Expected Completion Duration" was calculated by subtracting the date of site handover from the project completion date estimated in the contract, and then "Actual Completion Duration" was calculated by subtracting the actual start date from the actual date of project completion. "Durational Deviation of the Project" was calculated by subtracting expected completion duration from the actual completion duration, and this value was then divided by the expected completion duration to find "Durational Deviation" in terms of percent. This calculation was applied to all construction projects tendered between 1995 and 2009 under the old and current laws and listed on the basis of provinces and years (Turhan 2006).
By using these data, the construction projects were classified according to early finished, on-duration finished, and delayed, and the number of projects in each of these categories was determined so that the actual completion duration for a total number of 878 construction projects tendered under Laws No. 2886 between 1995 and 2002 could be determined. Then, for each group, the percentages were calculated by dividing the number of construction projects by total number of projects. The same procedure was applied to 575 construction projects tendered under Law No. 4734 between 2003 and 2009 (Table 2).

Table 2. Durational finish analysis of projects executed under Laws No. 2886 and 4734

\begin{tabular}{l|c|c|c|c}
\hline \multirow{2}{*}{$\begin{array}{c}\text { Durational finish } \\
\text { analysis of pro- } \\
\text { jects }\end{array}$} & \multicolumn{2}{|c|}{$\begin{array}{r}\text { Number of projects } \\
\text { executed between } \\
1995-2002 \text { under } \\
\text { Law No. 2886 }\end{array}$} & \multicolumn{2}{|c}{$\begin{array}{c}\text { Number of projects } \\
\text { executed between } \\
\text { 2003-2009 under } \\
\text { Law No. 4734 }\end{array}$} \\
\cline { 2 - 5 } & Frequency & $\%$ & Frequency & $\%$ \\
\hline $\begin{array}{l}\text { Number of pro- } \\
\text { jects finished } \\
\text { earlier }\end{array}$ & 176 & 20 & 270 & 47 \\
\hline $\begin{array}{l}\text { Number of pro- } \\
\text { jects finished on } \\
\text { duration }\end{array}$ & 266 & 30 & 189 & 33 \\
\hline $\begin{array}{l}\text { Number of de- } \\
\text { layed projects }\end{array}$ & 436 & 50 & 116 & 20 \\
\hline $\begin{array}{l}\text { Total Number of } \\
\text { Projects }\end{array}$ & $\mathbf{8 7 8}$ & $\mathbf{1 0 0}$ & $\mathbf{5 7 5}$ & $\mathbf{1 0 0}$ \\
\hline
\end{tabular}

According to these results, it was determined that $20 \%$ of the projects carried out under Law No. 2886 were completed early, $30 \%$ were finished on-duration, and $50 \%$ were completed with delay. On the other hand, $47 \%$ of the projects carried out under Law No. 4734 were completed early, $33 \%$ were finished on-duration, and $20 \%$ were completed with delay.

If early finished and on-duration finished construction projects are combined as "on-duration projects," it can be seen that only $50 \%$ of the construction projects that were tendered under the old law were completed onduration, whereas a higher percentage $(80 \%)$ of the construction projects that were tendered under the current law were completed on-time.

In addition, the results of this analysis on the basis of the numbers also show that only 176 out of 878 construction projects tendered under the old law were finished early, 266 were finished on time, and 436 were delayed. On the other hand, a much higher number of projects under the current law, 270 out of 575, were completed early, 189 were completed on time, and 116 were delayed.

The reviewed projects were grouped into certain ranges of delay duration because this grouping is important for the comparison of projects tendered under the two laws. In this context, delay percentage was calculated by subtracting expected completion duration from the actual completion duration, and then by dividing this value by the expected completion duration. Next, the projects were classified in $20 \%$ of delay intervals. Finally, the ratio of the 
Table 3. Delay percentage of completed projects under Laws No. 2886 and 4734 (\%)

\begin{tabular}{|c|c|c|c|c|}
\hline $\begin{array}{l}\text { Delay range of } \\
\text { projects } \\
(\%)\end{array}$ & $\begin{array}{l}\text { Number of projects } \\
\text { under Law No. } 2886 \\
\text { (a) }\end{array}$ & $\begin{array}{l}\text { Law No. } 2886 \\
(\mathrm{a} / 878)^{*} 100 \\
(\%)\end{array}$ & $\begin{array}{l}\text { Number of projects } \\
\text { under Law No. } 4734 \\
\text { (b) }\end{array}$ & $\begin{array}{c}\text { Law No. } 4734 \\
(\mathrm{~b} / 575)^{*} 100 \\
(\%)\end{array}$ \\
\hline$->40$ & 20 & 2 & 34 & 6 \\
\hline$-[20-40]$ & 25 & 3 & 49 & 9 \\
\hline$-[0-20]$ & 131 & 15 & 187 & 32 \\
\hline 0 & 266 & 30 & 189 & 33 \\
\hline$+[0-20]$ & 67 & 8 & 44 & 8 \\
\hline$+[20-40]$ & 95 & 11 & 19 & 3 \\
\hline$+>40$ & 274 & 31 & 53 & 9 \\
\hline Number of projects & 878 & 100 & 575 & 100 \\
\hline
\end{tabular}

-: Finished Earlier; 0: On Time; +: Delayed Projects

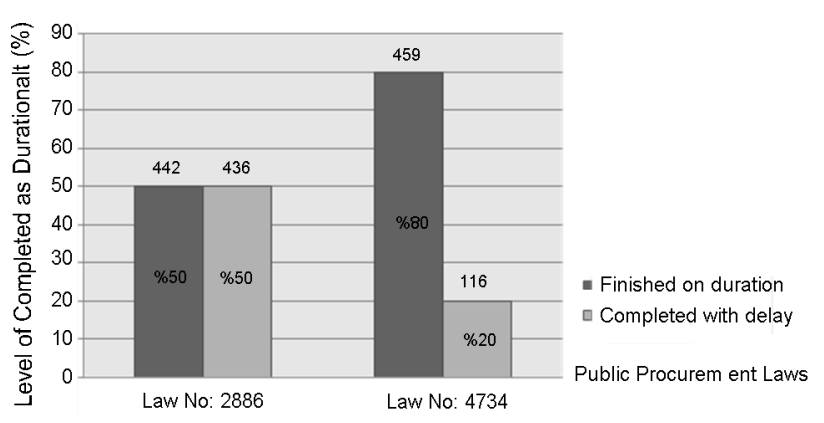

Fig. 1. Levels of completed as durational of construction projects executed with the Laws No. 2886 and 4743

number of projects that belongs to each $20 \%$ interval to total number of projects was calculated (Table 3 ).

Accordingly, $50 \%$ of the projects executed under the old law and $20 \%$ of the projects executed under the current law were completed later than the estimated duration, as shown in Table 3 and Fig. 1. Additionally, all projects tendered under the old law fell into three categories, as shown in Table 3 . These categories are early completed, in-duration completed, and late completed. Only $20 \%$ of total projects were early completed; and of these projects: $2 \%$ were completed early at a higher level of $40 \%$ of duration estimated; $3 \%$ were completed at the level of $40 \%$ earlier than duration estimated; and approximately $15 \%$ were finished early at a level of $20 \%$ of duration estimated. $30 \%$ of total projects were completed on-duration (i.e., at the estimated duration). $50 \%$ percent of total projects were late completed, and of these projects: $8 \%$ were completed later than $20 \%$ of duration estimated; $11 \%$ were completed later than $40 \%$ of the duration estimated; and $31 \%$ were finished much later than $40 \%$ of duration estimated. The reasons leading to more than $40 \%$ delays are the delayed launch of the work, late licensing, alteration of the project, the absence of or insufficient appropriations, and delays due to weather conditions and other causes.

On the other hand, all projects tendered according to the current law also fell in three categories, as shown in Table 3. However, almost half of these projects (47\%) were early completed, and of these projects: $6 \%$ were completed early at a higher level of $40 \%$ of duration estimated; $9 \%$ were completed at the level of $40 \%$ earlier than duration estimated; and approximately $33 \%$ were finished early at a level of $20 \%$ of duration estimated. $33 \%$ of these projects were completed on-duration (i.e., at the estimated duration). Only $20 \%$ of total projects were late completed, and of these projects: $8 \%$ were completed later than $20 \%$ of duration estimated; $3 \%$ were completed later than $40 \%$ of the duration estimated; and $9 \%$ were finished much later than $40 \%$ of duration estimated. The reasons leading to delays in the limited number of projects (i.e., $20 \%$ of total projects) are the late completion of work packages, delays in provision of technical control personnel, and delays due to weather conditions and other causes. In fact, these delays are not related to the actual realization of the project, but caused by late start of the project and unexpected conditions (Karsl 1998; Chang 2002; Aibinu, Odeyinka 2006; Lo et al. 2006).

\subsection{Analysis of cost deviations in construction projects carried out under the old and current public laws}

In this section of the study, cost deviation levels of construction projects tendered under the old and current laws were determined individually between the years 19952009. For determining the cost deviation ratios of these construction projects, first and second estimated costs, tender cost, and final actual cost were taken into consideration for the projects executed under the old law; approximate cost, contract cost, and final actual cost were considered for the projects executed under the current law.

For the evaluation of how the first estimated cost calculations reflects reality, the second estimated cost was determined for the construction projects tendered under the old law. This was done by adding increases in the original estimated cost to the first estimated cost and subtracting payment cuts. By applying the price cut discount to this calculated second estimated cost, discounted cost was determined. Then, material price differences were added (e.g., bond failure and delay penalty) to the discounted cost, and payment cuts were deducted to calculate the "Final Actual Cost". If there were estimated cost increases and cost differences, they were then added to the contract cost, and payment cuts were deducted again for determining the final actual cost in construction projects tendered according to the current law.

Afterwards, to compare cost deviations of the projects tendered under both laws in terms of actual costs, the project costs expended in different years were converted to 2010 prices with the use of "day coefficients" (Tables 4 and 5). 
Table 4. Classification of project costs on yearly basis and converted to 2010 prices for 878 construction projects tendered between 1995-2002 under Law No. 2886 (Euro)

\begin{tabular}{|c|c|c|c|c|c|c|c|c|c|c|c|}
\hline \multirow{3}{*}{ Years } & \multirow{3}{*}{$\begin{array}{l}\text { Proj. } \\
\text { No. }\end{array}$} & \multirow{3}{*}{$\begin{array}{l}\text { Day } \\
\text { coeff. } \\
2010 \\
(\mathrm{~K})\end{array}$} & \multicolumn{3}{|c|}{ Planned } & \multicolumn{2}{|c|}{ Accrued } & \multicolumn{4}{|c|}{$\begin{array}{l}\text { Comparison of accrued with planned } \\
\text { project costs }\end{array}$} \\
\hline & & & \multirow{2}{*}{$\begin{array}{l}\text { First esti- } \\
\text { mated cost } \\
\text { (a) }\end{array}$} & \multirow{2}{*}{$\begin{array}{c}\text { Tender } \\
\text { cost } \\
\text { (b) }\end{array}$} & \multirow{2}{*}{$\begin{array}{l}\text { Price cut } \\
(\mathrm{a}-\mathrm{b}) / \mathrm{a} \\
(\%)\end{array}$} & \multirow{2}{*}{$\begin{array}{l}\text { Second } \\
\text { estimated } \\
\text { cost } \\
\text { (c) }\end{array}$} & \multirow{2}{*}{$\begin{array}{l}\text { Final } \\
\text { actual } \\
\text { cost } \\
\text { (d) }\end{array}$} & \multicolumn{2}{|c|}{$\begin{array}{l}\text { Estimated cost } \\
\text { deviations }\end{array}$} & \multicolumn{2}{|c|}{$\begin{array}{l}\text { Tender cost } \\
\text { deviations }\end{array}$} \\
\hline & & & & & & & & $\begin{array}{c}\text { Value } \\
(\mathrm{e}=\mathrm{c}-\mathrm{a})\end{array}$ & $\begin{array}{c}\% \\
(\mathrm{e} / \mathrm{a})\end{array}$ & $\begin{array}{c}\text { Value } \\
(\mathrm{f}=\mathrm{d}-\mathrm{b})\end{array}$ & $\begin{array}{c}\% \\
(\mathrm{f} / \mathrm{b})\end{array}$ \\
\hline 1995 & \multirow{2}{*}{49} & \multirow{2}{*}{75.409} & 561 & 465 & \multirow{2}{*}{17} & 4687 & 4258 & 4126 & \multirow{2}{*}{735} & 3793 & \multirow{2}{*}{816} \\
\hline Converted to 2010 & & & 42304 & 35065 & & 353442 & 321092 & 311138 & & 286027 & \\
\hline 1996 & \multirow{2}{*}{34} & \multirow{2}{*}{41.78} & 266 & 197 & \multirow{2}{*}{26} & 1194 & 1061 & 928 & \multirow{2}{*}{349} & 864 & \multirow{2}{*}{439} \\
\hline Converted to 2010 & & & 11113 & 8231 & & 49885 & 44329 & 38772 & & 36098 & \\
\hline 1997 & \multirow{2}{*}{44} & \multirow{2}{*}{21.461} & 1140 & 928 & \multirow{2}{*}{19} & 3061 & 2612 & 1921 & \multirow{2}{*}{169} & 1684 & \multirow{2}{*}{182} \\
\hline Converted to 2010 & & & 24466 & 19916 & & 65692 & 56056 & 41226 & & 36140 & \\
\hline 1998 & \multirow{2}{*}{146} & \multirow{2}{*}{12.436} & 6440 & 5534 & \multirow{2}{*}{14} & 27719 & 25212 & 21279 & \multirow{2}{*}{330} & 19678 & \multirow{2}{*}{356} \\
\hline Converted to 2010 & & & 80088 & 68821 & & 344713 & 313536 & 264625 & & 244715 & \\
\hline 1999 & 174 & 8027 & 7212 & 5973 & 17 & 13544 & 11946 & 6332 & 88 & 5973 & 100 \\
\hline Converted to 2010 & $1 / 4$ & 0.021 & 57891 & 47945 & 17 & 108718 & 95891 & 50827 & 00 & 47946 & 100 \\
\hline 2000 & 176 & 854 & 25880 & 21793 & 16 & 48917 & 45790 & 23037 & 80 & 23997 & 110 \\
\hline Converted to 2010 & 170 & 4.034 & 125622 & 105783 & 10 & 237443 & 222264 & 111821 & 09 & 116481 & 110 \\
\hline 2001 & 122 & & 12622 & 9402 & 26 & 18493 & 16043 & 5871 & 17 & 6641 & 71 \\
\hline Converted to 2010 & 122 & 0.900 & 50046 & 37279 & 20 & 73325 & 63610 & 23279 & 41 & 26331 & 11 \\
\hline 2002 & 123 & 205 & 26500 & 18774 & 20 & 31942 & 23824 & 5442 & 21 & 5049 & 27 \\
\hline Converted to 2010 & 153 & 2.593 & 63468 & 44964 & 29 & 76501 & 57058 & 13033 & 21 & 12094 & 21 \\
\hline Total (Conver & ed to 2 & 10) & 454998 & 368094 & 19 & 1309719 & 1173836 & 854721 & 188 & 805742 & 219 \\
\hline
\end{tabular}

Table 5. Classification of project costs on yearly basis and converted to 2010 prices for 575 construction projects tendered bettween 2003-2009 under Law No. 4734 (Euro)

\begin{tabular}{|c|c|c|c|c|c|c|c|c|c|c|}
\hline \multirow{3}{*}{ Years } & \multirow{3}{*}{$\begin{array}{l}\text { Proj. } \\
\text { No. }\end{array}$} & \multirow{3}{*}{$\begin{array}{l}\text { Day coeff. } \\
2010 \\
(\mathrm{~K})\end{array}$} & \multirow{3}{*}{$\begin{array}{l}\text { Approximate } \\
\text { cost } \\
\text { (a) }\end{array}$} & \multirow{3}{*}{$\begin{array}{c}\text { Contract } \\
\text { cost } \\
\text { (b) }\end{array}$} & \multirow{3}{*}{$\begin{array}{l}\text { Price cut } \\
t=(a-b) / a\end{array}$} & \multirow{3}{*}{$\begin{array}{l}\text { Final } \\
\text { actual } \\
\text { cost } \\
\text { (c) }\end{array}$} & \multicolumn{4}{|c|}{ Comparison of costs } \\
\hline & & & & & & & \multicolumn{2}{|c|}{$\begin{array}{c}\text { Approximate cost } \\
\text { deviations }\end{array}$} & \multicolumn{2}{|c|}{$\begin{array}{c}\text { Contract cost } \\
\text { deviations }\end{array}$} \\
\hline & & & & & & & $\begin{array}{c}\text { Value } \\
(\mathrm{d}=\mathrm{c}-\mathrm{a})\end{array}$ & $\begin{array}{c}\% \\
(\mathrm{~d} / \mathrm{a})\end{array}$ & $\begin{array}{c}\text { Value } \\
(\mathrm{e}=\mathrm{c}-\mathrm{b})\end{array}$ & $\begin{array}{c}\% \\
(\mathrm{e} / \mathrm{a})\end{array}$ \\
\hline 2003 & \multirow[b]{2}{*}{125} & \multirow[b]{2}{*}{1.841} & 17464 & 11811 & \multirow[t]{2}{*}{32} & 12214 & -5250 & \multirow[b]{2}{*}{-30} & 403 & \multirow[b]{2}{*}{3} \\
\hline Converted to 2010 & & & 32151 & 21744 & & 22486 & -9665 & & 742 & \\
\hline 2004 & \multirow[b]{2}{*}{166} & \multirow[b]{2}{*}{1.586} & 30149 & 17001 & \multirow[t]{2}{*}{44} & 17392 & -12757 & \multirow[b]{2}{*}{-42} & 391 & \multirow[b]{2}{*}{2} \\
\hline Converted to 2010 & & & 47817 & 26964 & & 27584 & -20232 & & 620 & \\
\hline 2005 & \multirow[b]{2}{*}{144} & \multirow[b]{2}{*}{1.421} & 19953 & 12019 & \multirow[t]{2}{*}{40} & 12251 & -7702 & \multirow[b]{2}{*}{-39} & 232 & \multirow[b]{2}{*}{2} \\
\hline Converted to 2010 & & & 28353 & 17079 & & 17409 & -10945 & & 330 & \\
\hline 2006 & \multirow[b]{2}{*}{38} & \multirow[b]{2}{*}{1.340} & 13030 & 9163 & \multirow[t]{2}{*}{30} & 9163 & -3867 & \multirow[b]{2}{*}{-30} & 0 & \multirow[b]{2}{*}{0} \\
\hline Converted to 2010 & & & 17460 & 12278 & & 12278 & -5182 & & 0 & \\
\hline 2007 & \multirow[b]{2}{*}{48} & \multirow[b]{2}{*}{1.196} & 20572 & 13866 & \multirow[t]{2}{*}{33} & 13866 & -6706 & \multirow[b]{2}{*}{-33} & 0 & \multirow[b]{2}{*}{0} \\
\hline Converted to 2010 & & & 24604 & 16584 & & 16584 & -8021 & & 0 & \\
\hline 2008 & & & 12798 & 8168 & & 8168 & -4630 & & 0 & \\
\hline Converted to 2010 & 44 & 1.123 & 14372 & 9173 & 36 & 9173 & -5199 & -36 & 0 & 0 \\
\hline 2009 & & & 504 & 336 & & 336 & -168 & & 0 & \\
\hline Converted to 2010 & 10 & 1.026 & 517 & 345 & 33 & 345 & -173 & -33 & 0 & 0 \\
\hline Total (Con & $\operatorname{erted} t$ & 2010) & 165276 & 104167 & 37 & 105859 & -59416 & $-36-$ & 1693 & 1 \\
\hline
\end{tabular}


Following these calculations, first estimated cost, tender cost, and final actual cost of the projects tendered between 1995 and 2002 under the old law were determined as 454998 Euro, 368094 Euro, and 1173836 Euro, respectively. Similarly, approximate cost, contract cost, and final actual cost of the projects tendered between the years of 2003-2009 under the current law were found to be 165276 Euro, 104167 Euro, and 105859 Euro, respectively.

Moreover, the deviations between first and second estimated costs and between contract (tender) and final actual costs were found to be $188 \%$ and $219 \%$, respectively, for the projects tendered under the old law. On the other hand, the deviation between approximate and final actual costs and the deviation between final and contract actual costs were found to be about $-36 \%$ and $1 \%$, respectively, for the projects tendered under the current law (Tables 4 and 5).

From these results, it can be said that the large deviation between first and second estimated costs of the projects tendered under the old law (Law No. 2886) indicates that estimated cost (first estimated cost) is not realistic at all. In contrast, since final actual cost is well below the approximated cost, and since a negligible difference exists between contract and final actual costs, estimated cost (approximately cost) is quite realistic for the projects tendered under the current law.

To evaluate the cost deviation rates of the projects tendered under both old and current laws and to compare them with each other, the cost deviation levels were categorized in groups of $20 \%$ intervals. The number of projects falling into each group was determined, and their percentages with respect to the total number of projects were also calculated. Large quantities of deviations were determined with various reasons for a limited number of projects, and these exceptional deviations are presented under "other" results in Table 6.

As seen from Table 6, almost half of the projects (i.e., 41\%) executed under Law No. 2886 were realized with a very high cost deviation such as $40 \%$, leading to

Table 6. Cost deviation ranges of projects executed under Laws No. 2886 and $4734(\%)$

\begin{tabular}{|c|c|c|c|c|}
\hline $\begin{array}{l}\text { Cost } \\
\text { deviation } \\
\text { range of } \\
\text { projects } \\
(\%)\end{array}$ & $\begin{array}{l}\text { Number of } \\
\text { project } \\
\text { performed } \\
\text { under Law } \\
\text { No. } 2886 \\
\text { (a) }\end{array}$ & $\begin{array}{c}(\%) \\
(\mathrm{a} / 878)^{*} \\
100\end{array}$ & $\begin{array}{l}\text { Number of } \\
\text { project } \\
\text { performed } \\
\text { the Law } \\
\text { No. } 4734 \\
\text { (b) }\end{array}$ & $\begin{array}{c}(\%) \\
(\mathrm{b} / 575)^{*} \\
100\end{array}$ \\
\hline$->40$ & 1 & 0 & 0 & 0 \\
\hline$-[20-40]$ & 15 & 2 & 1 & 0 \\
\hline$-[0-20]$ & 115 & 13 & 65 & 11 \\
\hline 0 & 38 & 4 & 400 & 70 \\
\hline$+[0-20]$ & 225 & 26 & 109 & 19 \\
\hline$+[20-40]$ & 126 & 14 & 0 & 0 \\
\hline$+>40$ & 358 & 41 & 0 & 0 \\
\hline $\begin{array}{l}\text { Number } \\
\text { of projects }\end{array}$ & 878 & 100 & 575 & 100 \\
\hline
\end{tabular}

-: Below of the Cost; 0: Finished-on Cost; +: High cost deviation

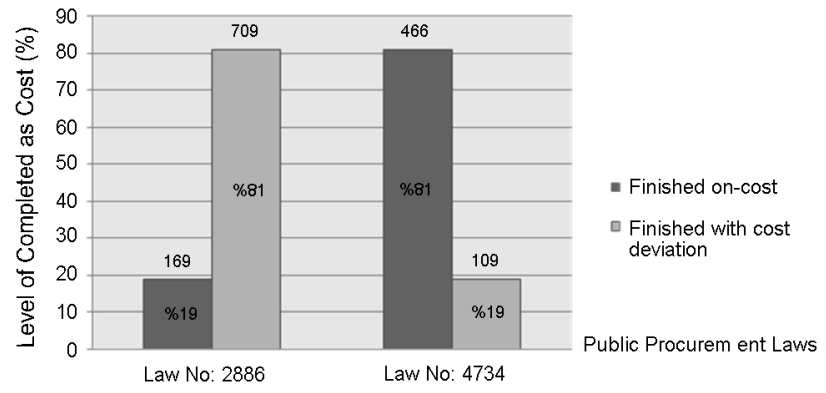

Fig. 2. Levels of completed as cost of construction projects executed with the Laws No. 2886 and 4743

an intolerable increase in cost. A cost increase of this level was not observed on the projects carried out according to the current Public Procurement Law No. 4734. Accordingly, $81 \%$ of the projects executed under the old law and $19 \%$ of the projects executed under the current law were completed later than estimated time because of deviations in estimated cost (the first estimated cost from Law No. 2886 and the approximate cost from Law No. 4734), as shown in Table 6 and Fig. 2.

\subsection{Prediction of the duration and cost deviations for construction projects}

In this part of the study, the question of whether the deviations in duration and cost of the construction projects can be estimated, even during the tender process, was examined. At this stage, deviations have been predicted by using the data mining method, including the DT, ANN, and SVM techniques. The factors causing deviations in the duration and cost of the investment (i.e., the procurement law under which the project is executed, the estimated or envisaged contract duration of the project, the location of tendering, and the estimated project cost and rate of price-cut), and whether the outcome was successful or unsuccessful, have been taken together as the data set.

Next, with the Clementine 12.0 software package employing all three techniques, using $80 \%$ of the data for training and the remaining $20 \%$ for testing, the predicts of deviations in the duration of the work and cost have been tested with the data mining method by using three different approaches. To define the prediction of data mining as successful, these predicts are expected to correspond to $75 \%$ of the learning process. In analysis of durational deviation, it was seen that the SVM technique succeeded by $74 \%$ in the training set and $79 \%$ in the test set, while the ANN technique succeeded by $73 \%$ in the training set and $78 \%$ in the test set, as noted in Table 7. By using the C5 algorithm with the DT method, the success rate was increased to $76 \%$ in the training set and $76 \%$ in the test set. In analyzing the deviation in cost (i.e., the first estimated cost mentioned in Law No. 2886 and the approximate cost mentioned in Law No. 4734), the SVM technique succeeds by $82 \%$ in the training set and $87 \%$ in the test set, while the ANN technique succeeds by $84 \%$ in the training set and $88 \%$ in the test set. If the DT algorithm is used, the success rate is $88 \%$ in the training set and $87 \%$ in the test set. Finally, the success rate for each 
Table 7. Models used to estimate the deviations of contract duration and approximate cost of construction projects and levels of deviation estimates of these models

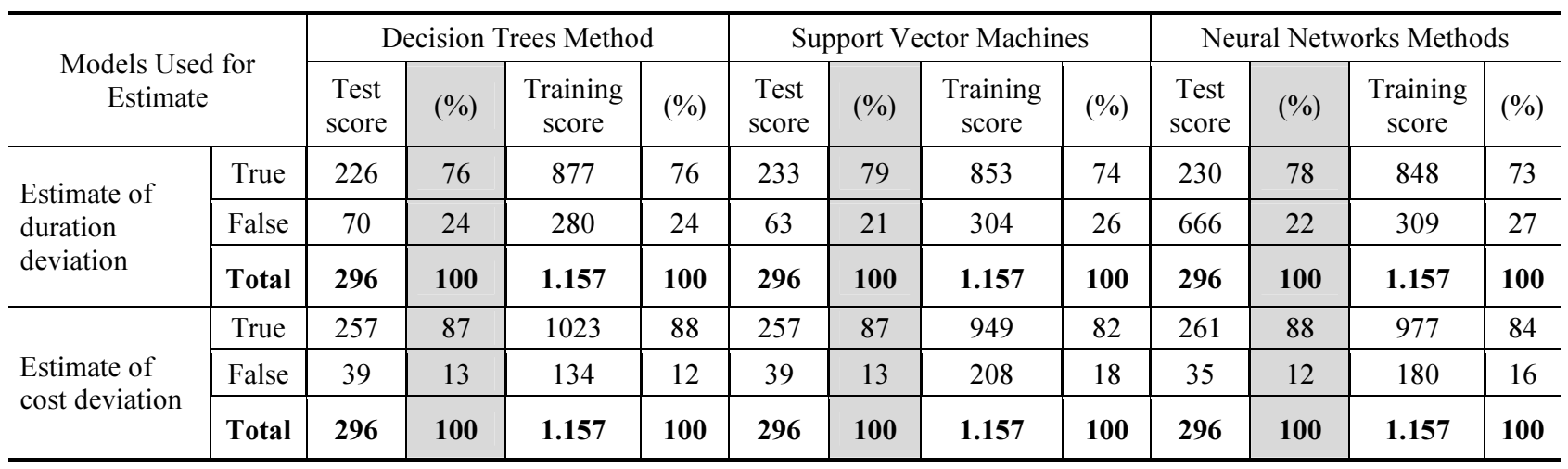

of the three approaches is approximately $76 \%$ for the estimate of durational deviations and $86 \%$ for cost deviations. Therefore, it is concluded that the possible duration and cost deviations can be estimated in the procurement process by using these techniques.

As seen from Table 7, all three techniques employed in determining the durational and cost deviations yielded approximately the same results. Moreover, SVM was the more accurate technique employed, followed by ANN and DT. By examining data regarding the degree of importance of variables, the most important factors causing deviations in the duration and cost of the project can be listed with the order of the procurement law used, the estimated or envisaged duration of the project, the location of tendering, the estimated cost of tender, and the rate of price-cut.

Within the scope of the present study, by using the DT technique, a total of 1453 records have been entered in C5.0 algorithm, the decision tree has been trained with a set of data with a known target variable, and a model that will provide information about the duration and cost deviations has been created. The performance of the model has been measured by testing it on a new set of data where the dependent variable is not specified. For this reason, in order to create the model, 1157 pieces of the data set have been selected randomly among the 1453 pieces used as the training data set. The model has been trained with $80 \%$ of the data and tested by the remaining $20 \%$.

Since this study is based on research about the innovations brought by the current procurement law in comparison with the old one, only the procurement law variable obtained from the DT model has been examined. The DT model developed to determine the factors affecting deviations in duration and cost of investments is shown in Figs 3 and 4.

As seen from Fig. 3, the variable with the strongest effect is the procurement law variable. It is seen that there exists no durational deviations in $63.354 \%$ of the projects, while there is durational deviations in $36.646 \%$ of the projects carried out under the old and current procurement laws. Among 1157 of tenders, $60.847 \%$ has been carried out under the old law and $39.153 \%$ has been carried out under the current law.

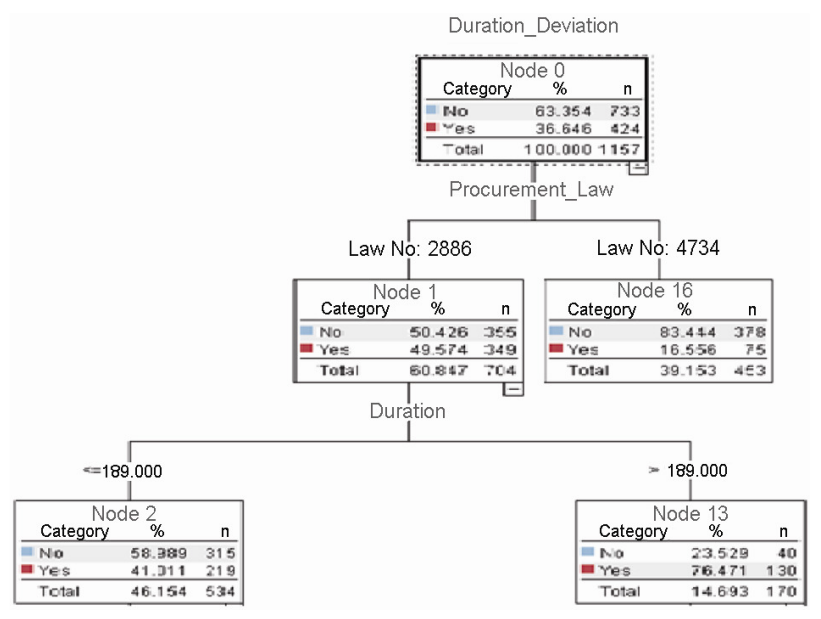

Fig. 3. Factors affecting durational deviations in construction projects

Note: Other factors (i.e., the estimated or envisaged duration of the project, the location of tendering, the approximate cost of tender, and the rate of price-cut) affecting durational deviation are not included in the DT model because this study concentrates on the importance of procurement law.

Under the old law, there were 704 tender samples used in this study, while 453 were made under the current law. As shown in Fig. 3, it is found that there is no durational deviation in 355 of the tenders under the former law, while there is durational deviation in the remaining 349 tenders. Similarly, it is seen that there is no durational deviation in 378 of 453 tenders under the current law, and there is durational deviation in only 75 of them. According to the, if the tender is made under the current law, the probability of durational deviation is $16.556 \%$. On the other hand, if the tender is made under the old law, the probability of durational deviation is $49.574 \%$. This shows that there is compatibility between these results and the research findings $(50 \%$ of the projects executed under the old law and $20 \%$ of the projects executed under the new law have durational deviation). Thus, it can be said that the possibility of durational deviation in tenders made under the old law is approximately 3 times greater than those made under the current law. 


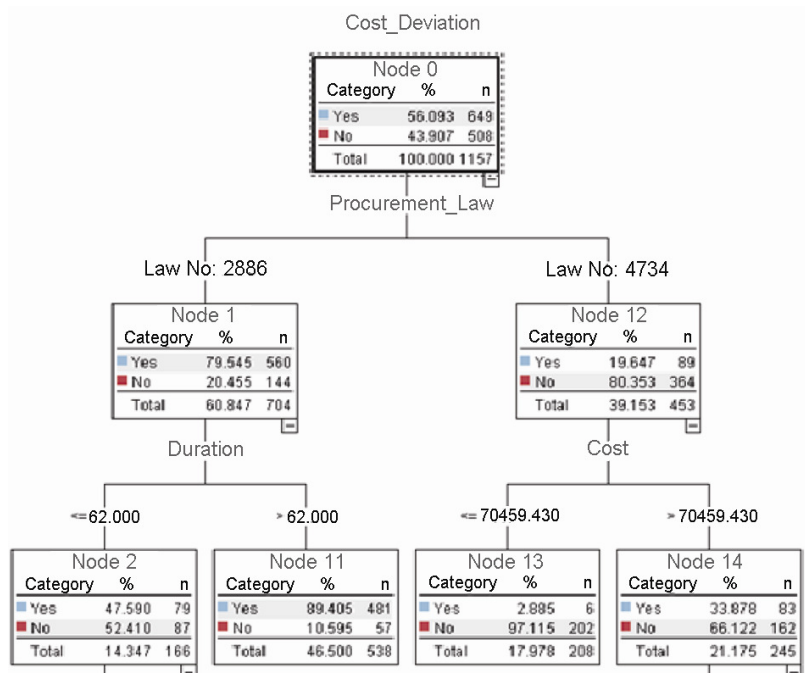

Fig. 4. Factors affecting cost deviations in construction projects

Note: Other factors (i.e., the estimated or envisaged duration of the project, the location of tendering, the approximate cost of tender, and the rate of price-cut) affecting cost deviation are not included in the DT model because this study concentrates on the importance of procurement law.

As seen from Fig. 4, the strongest variable influencing the cost is the procurement law, as in the DT root affecting the durational deviation. At the root of the DT of the 1157 tenders, there is no cost deviation for $43.907 \%$ of all projects under the old and the current laws, while a cost deviation was observed in $56.093 \%$ of projects. Fig. 4 also shows that $60.847 \%$ of 1157 tenders were made under the old procurement law, and $39.153 \%$ were made under the current procurement law.

Under the old law, there were 704 samples, and 453 were made under the current law. As shown in Figure 4, it is observed that there is deviation in estimated cost (first estimated cost) in 560 of 704 tenders under the old law, and there is no estimated cost deviation in 144 tenders. Similarly, it is seen that there is no deviation in the estimated cost (approximate cost) in 364 of 453 tenders under the current law, and there are estimated cost deviations in 89 tenders. According to the DT, if the tender has been made under the current law, the probability of deviation in the estimated cost is $19.647 \%$, whereas the probability of deviation in the estimated cost is $79.545 \%$ if the tender is made under the old law. This shows that there is compatibility between these results and the research findings $(81 \%$ of the projects executed under the old law and $19 \%$ of the projects executed under the current law have estimated cost deviations). Thus, it can be concluded that the possibility of deviation in the estimated cost in tenders made under the old law is substantially larger than those made under the current law.

\section{Conclusions}

Construction investments constitute a large portion of public procurement in Turkey. Countries, particularly developing ones such as Turkey, should seek ways for creating competitive environments in tenders to provide higher quality goods or services at lower costs for future construction investments. In doing so, significant levels of resource savings in public expenses can be assured. To achieve this objective, the public procurement law was changed, and the current law was put into effect in 2003 under Law No. 4734.

Bearing in mind that the current law contains many important improvements, this study was conducted to determine the contributions of the current law towards the estimation of more realistic expected cost and completion duration for construction projects. For this purpose, numerous public construction projects tendered between the years of 1995-2009 under the old and current laws were evaluated. The followings results were obtained from the present work:

1. Fifty percent of the projects executed under the old law were completed later than estimated duration. On the other hand, this was only $20 \%$ for the projects executed under the current law. Approximately $31 \%$ of projects executed under the old law had a delay level higher than $40 \%$, whereas only $9 \%$ of the projects executed under the current law had such a delay.

2. Similarly, only $20 \%$ of projects executed under the old law were completed at estimated project cost, whereas $80 \%$ projects executed under the current law were completed at the estimated cost or lower. Moreover, the deviations between contract and final actual costs were about $219 \%$ and $1 \%$ for the projects executed under the old and current laws, respectively. The reason for much higher deviation for the projects executed under the old law is due to the unrealistic cost calculations at the beginning of the work.

3. The duration and cost increases in construction projects carried out under Law No. 2886 originated from: (1) the insufficient details in the preparation of the contracts and their supplements (e.g., the possibility of tendering with estimated tender costs without preparing any application project drawings, and the variations in the amount of work that results from the increase in quantities and changes in qualifications during the construction process); (2) incompleteness of contractor selection methods (e.g., lack of a detailed analysis of price because the old law used unit price methods as the tender procedure, and high amounts of discounts on the price by bidders); (3) lack of the application of management functions (e.g., planning, organization, coordination, and command and control) from the beginning to the end of the work due to various reasons; and (4) low values of constructional productivity due to various reasons and (5) external factors such as negative market conditions and price changes. These deviations result in failure in balancing public budgets as foreseen, in project delays due to the lack of resources, and in the increase of project costs due to inflation.

4. On the other hand, although envisaged and completed project durations in construction projects carried out under Law No. 4734 were similar to those of the projects conducted by the old law due to the "Turnkey" tender type of the current law, duration and cost increases rarely occurred in construction projects that carried out under 
Law No. 4734. The reasons for these rare duration and cost increases were the lack of the application of management functions from the beginning to the end of the work due to various reasons and external factors.

5. This study was also conducted to assess whether duration and cost deviations of construction projects at the stage of the tender process can be determined. In the study, whether the deviations in duration and cost of the construction projects can be predicted by using the data mining method, including the DT, ANN and SVM techniques, was investigated. For the prediction of durational deviation, the success rates were by $79 \%, 78 \%$, and $76 \%$, respectively, if the SVM, ANN, and DT techniques were used. Similarly, for the prediction of cost deviation, the success rates were $87 \%, 88 \%$, and $87 \%$, respectively, if the SVM, ANN, and DT techniques were used. These results indicate that the success level of the estimation of durational and cost deviations can be increased by the use of SVM and ANN techniques.

6 . Each of the three techniques used in this study has been well demonstrated to be very successful for this purpose (i.e., an average of $76 \%$ for the estimation of durational deviations and an average of $86 \%$ for cost deviations). Although this study was conducted considering only the limited data existing in the files of tender process, the durational and cost deviations were estimated with success rates of $76 \%$ and $86 \%$, respectively. These results indicate that even durational and cost deviations of $20 \%$ of public construction investments, which were realized following enactment of the current procurement law, can be reasonably estimated as early as during the tender process by these techniques. The results also indicate that the most important factor causing deviations in contract duration and cost are as follows:

- The procurement law under which the project is executed;

- The project estimated cost;

- The estimated or envisaged duration of the project;

- The rate of price-cut;

- Location/provincial of project.

7. In this study, the improvements of the current law related to in-time completion and completion at the expected cost of the constructional projects were also determined. The results indicated that the most important variable existing in the root of the DT technique was that of the procurement law. It was also determined that the possibility of durational deviation was approximately $50 \%$ if the tender process was conducted under Law No. 2886, whereas it was only approximately $17 \%$ if the tender process was conducted under Law No. 4734. This clearly shows that the DT results are in good agreement with the results of analysis (i.e., 50\% for Law No. 2886 and $20 \%$ for Law No. 4734).

8. According to the results of the DT technique, the possibility of cost deviation was approximately $80 \%$ if the tender process was conducted under Law No. 2886, whereas it was only approximately $20 \%$ if the tender process was conducted under Law No. 4734. This clearly indicates that the DT results are in good agreement with the results of analysis (i.e., $80 \%$ for Law No. 2886 and $20 \%$ for Law No. 4734). Finally, the results of the DT technique clearly show that the possibility of durational deviation encountered in the completed constructional projects conducted under Law No. 2886 was approximately 3 times that occurring in the projects under Law No. 4734. Similarly, the possibility of cost deviation encountered in the completed constructional projects conducted under Law No. 2886 was much higher than that occurring in the projects under Law No. 4734.

9. Undoubtedly, for a successful estimation of duration and cost by these techniques, needed are the data related to: (1) managerial and technical characteristics of the contracts and its supplements (the projects and technical specifications) from the beginning to the end of the work for each constructional project; (2) contractor selection methods (procurement method); (3) the application of management functions (planning, organization, coordination, and command and control) from the beginning to the end of the work; (4) the values of productivity of the constructional activities; and (5) the data originating from external factors affecting the duration and cost of the work. The success of the durational and cost related estimations can be increased by using these data in future studies.

10. Finally, it can be concluded that the current law has contributed substantially towards the completion of the projects in estimated or envisaged duration and at estimated cost. In this respect, the current law is a felicitous arrangement. Moreover, work is currently in progress to facilitate tenders to be made electronically, which is expected to further increase the effectiveness of the law.

\section{Acknowledgements}

The author would like to thank Prof. Dr M. Emin Öcal, Prof. Dr Emel Oral and Asst. Prof. Dr İbrahim Halil Gerek for their invaluable contributions to the current work. And finally would like to thank to Nuray Turhan (Msc) for her contribution during data collection stage.

\section{References}

Abacıŏlu, M. 1999. Devlet ihale kanunu ve ilgili mevzuat 2 [State procurement law and related legislation 2]. Bask1, Ankara: Seçkin Yayınevi. 509 p.

Abu Hammad, A. A.; Ali, S. M. A.; Sweis, G. J.; Bashir, A. 2008. Prediction model for construction cost and duration in Jordan, Jordan Journal of Civil Engineering 2(3): 250266.

Akintoye, A. 2000. Analysis of factors influencing project cost estimating practice, Construction Management and Economics 18(1): 77-89. http://dx.doi.org/10.1080/014461900370979

Akintoye, A.; Fitzgerald, E. 2000. A survey of current cost estimating practices in the UK, Construction Management and Economics 18(2): 161-172. http://dx.doi.org/10.1080/014461900370799

Aibinu, A. A.; Odeyinka, A. 2006. Construction delays and their causative factors in Nigeria, Journal of Construction Engineering and Management ASCE 132(7): 667-677. http://dx.doi.org/10.1061/(ASCE)0733-9364(2006)132: 7(667) 
Akpınar, H. 2000. Veri tabanlarında bilgi keşfi ve veri madenciliği [Knowledge Discovery in Databases and Data Mining], İstanbul Üniversitesi İşletme Fakültesi Dergisi [Journal of Istanbul University, Faculty of Business Administration] 29(1): 1-22.

Arrowsmith, S.; Kunzlik, P. 2009. Social and Environmental Policies in EC Procurement Law. Cambridge: Cambridge University Press. $106 \mathrm{p}$.

http://dx.doi.org/10.1017/CBO9780511576041

Arslan, A. 2002. 2886 say1lı kanun ile 4734 sayılı kamu ihale kanununun karşılaştırılması [Comparison of public procurement law by Law No. 2886 and No. 4734], Mali Kllavuz Dergisi [Journal of Financial Guidance] 19: 41-66.

Bhokha, S.; Ogunlana, S. O. 1999. Application of artificial neural network to forecast construction duration of buildings at the pre-design stage, Engineering, Construction and Architectural Management 6(2): 133-144.

Bromilow, F. J. 1969. Contract time performance expectations and the reality, Building Forum 1(3): 70-80.

Chan, D. W. M.; Kumaraswamy, M. M. 1999. Modelling and predicting construction durations in Hong Kong public housing, Construction Management and Economics 17(3): 351-362. http://dx.doi.org/10.1080/014461999371556

Chan, S. L.; Park, M. 2005. Project cost estimation using principal component regression, Construction Management and Economics 23(3): 295-304.

http://dx.doi.org/10.1080/01446190500039812

Chang, A. S.-T. 2002. Reasons for cost and schedule increase for engineering design projects, Journal of Management in Engineering ASCE 18(1): 29-36. http://dx.doi.org/10. 1061/(ASCE)0742-597X(2002)18:1(29)

Cheng, M.-Y.; Peng, H.-S.; Wu, Y.-W.; Chen, T.-L. 2010. Estimate at completion for construction projects using evolutionary support vector machine inference model, Automation in Construction 19(5): 619-629.

http://dx.doi.org/10.1016/j.autcon.2010.02.008

Dissanayaka, S. M.; Kumaraswamy, M. M. 1999. Evaluation of factors affecting time and cost performance in Hong Kong building projects, Engineering, Construction and Architectural Management 6(3): 287-298.

Doloi, H.; Sawhney, A.; Iyer, K. C.; Rentala, S. 2012. Analysing factors affecting delays in Indian construction projects, International Journal of Project Management 30(4): 479-489. http://dx.doi.org/10.1016/j.ijproman.2011.10.004

Dursun, O.; Stoy, C. 2011. Time-cost relationship of building projects: statistical adequacy of categorization with respect to project location, Construction Management and Economics 29(1): 97-106.

http://dx.doi.org/10.1080/01446193.2010.528437

Elhag, T. M. S.; Boussabaine, A. H.; Ballal, T. M. A. 2005. Critical determinants of construction tendering costs: quantity surveyors' standpoint, International Journal of Project Management 23(7): 538-545. http://dx.doi.org/10.1016/j.ijproman.2005.04.002

Emek, U. 2001. Kamu alımlarında etkin ihale tasarımı, Türk sanayicileri ve íş adamları derneği (TUSIAD) raporu [Design of effective public procurement tender, the Turkish Industrialists and Businessmen's Association (TUSIAD) report], Lebib Yalkın Yayımları ve Basım Isleri A.S, İstanbul, Türkiye.

Ertaş, R. C. 2010. Kamu kaynaklarının etkin kullanımı açısından kamu ihale kanununda öngörülen ihale usullerinin incelenmesi ve değerlendirilmesi [Effective use of public resources provided for the public procurement law, investigation and evaluation of procurement procedures]. Master thesis. Gazi Üniversitesi, Sosyal Bilimler Enstitüsü. 168 p.

European Union Delegation of the European Commission to Turkey. 2000. AB' de Kamu Ihaleleri [In the EU Public Procurement]. Ankara, Türkey.

Gencer, H. 2003. Kamu bina yapım ihalelerinde 2886 sayılı devlet ihale kanunu ile 4734 sayılı kamu ihale kanunu'nun karşılaştırılması [Public building construction tenders and public procurement law No. 2886, Comparison of Public Procurement Law No. 4734]. TIM-SE Dergisi [Journal of TEA-SE] 207: 14-19.

Gorecki, P. N. 2006. Kamu alimlarinin ekonomik ve sosyal politika araci olarak kullanimi, II [Using public procurement as a tool for economic and social policy, II], in Uluslararası Kamu Alımları Sempozyumu, Kamu İhale Kurumu Yayınları [International Symposium on Public Procurement, Public Procurement Agency Publications]. $16 \mathrm{p}$.

Göçerler, A. 2002. Kamu ihale kanunu'nun getirdiği yenilikler [The innovations of the Public Procurement Law] [online]. [Cited 15 January 2011]. Available from Internet: http://www.icisleri.gov.tr/\%20Icisleri/WPX/\%20kamu\%2 0ihale\%20kanunu.htm

Gök, Y. 2003. Sorular ve cevaplarla açıklamalı kamu ihale kanunu, 1 [Questions and answers to explain the public procurement law, 1]. bask1, Ankara: İlksan Matbaası. 656 p.

Gönen, D.; Işık, H. 1997. Açıklamalı devlet ihale kanunu ve yapım sözleşmelerinin uygulanması [Explaining the implementation of the public procurement law in construction contracts]. Ankara: TŞOF Plaka Matbaacılık Tic. ve San. A.Ş. 10.bask1. 1292 p.

Gören, S. G. 1998. Kamu inşaat projelerinin gerçekleştirilmesinde süre uzama nedenlerinin analizi [Analysis of public construction projects' prolonged period of time]. $\mathrm{PhD}$ thesis. İTÜ Fen Bilimleri Enstitüsü.

Güreş, T. 1998. Kamuya ait inşaat işlerinde süre uzatımı ve ödenek aktarımı ihtilafları [Extension of time and funds transfer of state-owned construction work conflicts]. Master Thesis. ODTÜ, Fen Bilimleri Enstitüsü.

Holt, G. D. 1998. Which contractor selection methodology?, International Journal of Project Management 16(3): 153164. http://dx.doi.org/10.1016/S0263-7863(97)00035-5

İşaat Sektörü [Construction Sector], [online]. 2011. [Cited 15 January 2011]. Available from Internet: http://www. mutluturk.com.tr/

Kamu İhale Kurumu [The Public Procurement Authority]. 2011. 2010 Yılı 12 Aylık Kamu Alımları İstatistikleri [Public procurement statistics of 12 months, year 2010] [online]. [Cited 15 May 2011]. Available from Internet: http://www.ihale.gov.tr/Istatistikler_Raporlar/ihale_istatis tikleri.htm

Kanoğlu, A. 2003. An integrated system for duration estimation in design/build projects and organizations, Engineering, Construction and Architectural Management 10(4): 272282. http://dx.doi.org/10.1108/09699980310489988

Karsl1, E. D. 1998. Inşaat süresini etkileyen faktörler ve inşaat süresi tahmin modelleri [Factors affecting the duration of the construction period and construction prediction models]. Master Thesis. İTÜ Fen Bilimleri Enstitüsü.

Kim, B. S. 2011. The approximate cost estimating model for railway bridge project in the planning phase using CBR method, KSCE Journal of Civil Engineering 15(7): 11491159. http://dx.doi.org/10.1007/s12205-011-1342-2 
Kim, G.-H.; An, S.-H.; Kang, K.-I. 2004. Comparison of construction cost estimating models based on regression analysis, neural networks, and case-based reasoning, Building and Environment 39(10): 1235-1242.

http://dx.doi.org/10.1016/j.buildenv.2004.02.013

Koushki, P. A.; Al-Rashid, K.; Kartam, N. 2005. Delays and cost increases in the construction of private residential projects in Kuwait, Construction Management and Economics 23: 285-294. http://dx.doi.org/10.1080/0144619042000326710

Liao, T. S.; Wang, M. T.; Tserng, H. P. 2002. A framework of electronic tendering for government procurement: a lesson learned in Taiwan, Automation in Construction 11(6): 731-742.

http://dx.doi.org/10.1016/S0926-5805(02)00013-4

Lo, T. Y.; Fung, I. W.; Tung, K. C. 2006. Construction delays in Hong Kong civil engineering projects, Journal of Construction Engineering and Management ASCE 132(6): 636-649. http://dx.doi.org/10.1061/(ASCE)07339364(2006)132:6(636)

Luu, D. T.; Ng, S. T.; Chen, S. E. 2003. A case-based procurement advisory system for construction, Advances in Engineering Software 34(7): 429-438. http://dx.doi.org/10.1016/S0965-9978(03)00043-7

Öcal, M. E.; Paydak, O.; Oral, E. L. 2006. Public procurement law in Turkey, Journal of Professional Issues in Engineering Education and Practice ASCE 132(2):153-155. http://dx.doi.org/10.1061/(ASCE)1052-3928(2006)132: 2(153)

Özmen, S. 2001. İs hayati veri madenciliği ile istatistik uygulamalarini yeniden keşfediyor [Data mining and statistical applications in business life rediscovers], [cited 15 May 2011]. Available from Internet: http//www.idari.cu.edu.tr/ sempozyum/bil38.htm

Paydak, O. 2002. Avrupa Birliği ve ülkemizde uygulanmakta olan ihale mevzuatınin irdelenmesi [Analysis of the European Union and procurement legislation which was implemented]. Master Thesis. Çukurova Üniversitesi Fen Bilimleri Enstitüsü.

2886 Sayılı Devlet İhale Kanunu [Public Procurement Law No. 2886], Resmi Gazete-18161 sayll [Official Gazette No. 18161], 1983. Ankara, Turkey.

4734 Sayılı Devlet Ihale Kanunu [Public Procurement Law No. 4734], Resmi Gazete-24648 sayll [Official Gazette No. 24648], 2002. Ankara, Turkey.

Sarıtaş, O. 2006. Türk inşaat sektörü [Turkish construction sector], [cited 15 January 2006]. Available from Internet: http://web.itu.edu.tr/\%20 saritas/Turk\%20İnsaat\%20Sekt oru.pdf

Skitmore, R. M.; Ng, S. T. 2003. Forecast models for actual construction time and cost, Building and Environment 38(8): 1075-1083.

Strain, J. D.; Preece, D. A. 1999. Project management and the integration of human factors in military system procurement, International Journal of Project Management 17(5): 283-292.

http://dx.doi.org/10.1016/S0263-7863(98)00044-1
Tserng, H. P.; Lin, P. H. 2002. An accelerated subcontracting and procuring model for construction projects, Automation in Construction 11(1): 105-125.

http://dx.doi.org/10.1016/S0926-5805(01)00056-5

Turhan, N. 2006. Kamu ihale sistemindeki değişikliğin inşaat yatırımlarınin süre ve maliyetine yansimalar [Investments in the public procurement system, change of construction time and cost implications]. Master Thesis. Çukurova Üniversitesi Fen Bilimleri Enstitüsü.

Tzeng, W.-L.; Li, J. C.-C.; Chang, T.-Y. 2006. A study on the effectiveness of the most advantageous tendering method in the public works of Taiwan, International Journal of Project Management 24(5): 431-437. http://dx.doi.org/10.1016/j.ijproman.2006.02.007

Wang, Y.-R.; Yu, C.-Y.; Chan, H.-H. 2012. International predicting construction cost and schedule success using artificial neural networks ensemble and support vector machines classification models, International Journal of Project Management 30(4): 470-478.

http://dx.doi.org/10.1016/j.ijproman.2011.09.002

Williams, T. P. 2002. Predicting completed project cost using bidding data, Construction Management and Economics 20(3): 225-235. http://dx.doi.org/10.1080/01446190110112838

Williams, T. P. 2003. Predicting final cost for competitively bid construction projects using regression models, International Journal of Project Management 21(8): 593-599. http://dx.doi.org/10.1016/S0263-7863(03)00004-8

Wright, M. G.; Williams, T. P. 2001. Using bidding statistics to predict completed construction cost, The Engineering Economist 46(2): 114-128. http://dx.doi.org/10.1080/00137910108967565

Yakut, E.; Elmas, B. 2011. İşletmelerin mali başarısızlığının veri madenciliği ve diskriminant analizi modelleri ile tahmin edilmesi [Financial business and discriminant analysis models with data mining prediction of failure], in Finans Sempozyumu [Finance Symposium], 2011, Malatya, 15.

Yalazay, S. 2010. Eşitlik ilkesi çerçevesinde 4734 sayılı kamu ihale kanunu kapsamindaki ihalelerde tekliflerin hazırlanması, sunulması ve değerlendirilmesi usulü [4734 within the framework of the principle of equality under the law of public procurement tenders, bid preparation, submission and evaluation procedure]. Master thesis. Gazi Üniversitesi, Sosyal Bilimler Enstitüsü [Gazi University, Institute of Social Sciences]. $140 \mathrm{p}$.

Yoo, W. S. 2007. An Information-based decision making framework for evaluating and forecasting a project cost and completion date. $\mathrm{PhD}$ thesis. The Graduate School of The Ohio State University, USA. 305 p.

Zhiliang, M.; Zhenhua, W.; Wu, S.; Zhe, L. 2011. Application and extension of the IFC standard in construction cost estimating for tendering in China, Automation in Construction 20(2): 196-204.

http://dx.doi.org/10.1016/j.autcon.2010.09.017

Ercan ERDIS. Assistant Professor of Civil Engineering in the Faculty of Engineering at Mustafa Kemal University. Dr Erdis is a member of Chamber of Civil Engineers of Turkey. Dr Erdis is actively involved in construction management areas. Dr Erdis received his MS and PhD degrees in Civil Engineering at the Mustafa Kemal University in 2001 and Cukurova University in 2004 , respectively. 